\title{
Uji Kualitatif dan Uji Aktivitas Antioksidan Ekstrak Etanolik Buah Maja (Aegle Marmelos (L.)Correa) dengan Metode DPPH
}

\author{
Muhammad Nur Fauzi ${ }^{*}$, Joko Santoso \\ Program DIII Farmasi, Politeknik Harapan Bersama Tegal, Jl. Mataram No.9, \\ Tegal 52147, Indonesia. \\ *nurfauzi24dec@gmail.com, jokosantoso@unisba.ac.id
}

\begin{abstract}
Indonesia is a country with the third largest tropical forest in the world. The number of medicinal plants in Indonesia is estimated to be around 1,260 types of plants. Plants produce secondary metabolites that have potential as antioxidants. One of the plants that contains a lot of secondary metabolites is maja (Aegle marmelos (L.) Corr). The purpose of this study was to determine the content of secondary metabolites in maja fruit extracts and to determine the antioxidant activity contained in maja fruit extracts using the DPPH method. The research was conducted by extracting maja fruit samples using maceration method to obtain a thick extract. The extracts obtained were tested for secondary metabolites, TLC test, and antioxidant activity tests using the DPPH method using Uv-vis spectrophotometry. The results of this study indicate that maja fruit extract contains secondary metabolites of flavonoids, tannins, alkaloids, saponins, and glycosides. TLC results obtained Rf 0.512 . The result of antioxidant activity of maja fruit extract obtained by IC50 was $269.153 \mu \mathrm{g} / \mathrm{mL}$. and IC50 vitamin C as a comparison obtained $28,907 \mu \mathrm{g} / \mathrm{mL}$. This shows that the antioxidant activity of maja fruit extract is smaller than the antioxidant activity of vitamin $\mathrm{C}$.
\end{abstract}

Keywords: Secondary Metabolites, Antioxidants, Maja Fruit (Aegle marmelos (L.) Correa)

\begin{abstract}
Abstrak. Indonesia adalah negara dengan hutan tropis paling besar ketiga di dunia, Jumlah tumbuhan berkhasiat obat di Indonesia diperkirakan sekitar 1.260 jenis tumbuhan. Tumbuhan menghasilkan metabolit sekunder yang berpotensi sebagai antioksidan. Salah satu tanaman yang banyak mengandung metabolit sekunder adalah tanaman maja (Aegle marmelos (L.) Corr). Tujuan dari penelitian ini adalah untuk mengetahui kandungan metabolit sekunder pada ekstrak buah maja dan untuk mengetahui aktivitas antioksidan yang terdapat pada ekstrak buah maja dengan metode DPPH. Penelitian dilakukan dengan mengekstraksi sampel buah maja dengan metode maserasi untuk memperoleh ekstrak kental. Ekstrak yang diperoleh dilakukan uji metabolit sekunder, uji KLT, dan uji aktivitas antioksidan dengan metode DPPH menggunakan spektrofotometri Uv-vis. Hasil penelitian ini menunjukkan bahwa ekstrak buah maja mengandung metabolit sekunder flavonoid, tanin, alkaloid, saponin, dan glikosida. Hasil KLT diperoleh Rf 0,512 . Hasil aktivitas antioksidan ektrak buah maja yang diperoleh dengan IC50 adalah $269,153 \mu \mathrm{g} / \mathrm{mL}$. dan IC50 vitamin c sebagai pembanding diperoleh $28,907 \mu \mathrm{g} / \mathrm{mL}$. hal ini menunjukan bahwa daya aktivitas antioksidan ekstrak buah maja lebih kecil dibanding dengan daya aktivitas antioksidan vitamin C.
\end{abstract}

Kata Kunci: Metabolit Sekunder, Antioksidan, Buah Maja (Aegle marmelos (L.) Correa) 


\section{A. Pendahuluan}

Indonesia adalah negara dengan hutan tropis paling besar ketiga di dunia (setelah Brazil dan Zaire). Keanekaragaman hayati merupakan basis berbagai pengobatan dan penemuan industri farmasi dimasa mendatang. Jumlah tumbuhan berkhasiat obat di Indonesia diperkirakan sekitar 1.260 jenis tumbuhan. Tumbuhan menghasilkan metabolit sekunder yang berpotensi sebagai antioksidan, zat perwarna, penambah aroma makanan, parfum, insektisida dan obat. Ada 150.000 metabolit sekunder yang sudah diidentifikasi dan ada 4000 metabolit sekunder "baru" setiap tahun (Yuhernita \& Juniarti, 2011)

Salah satu tanaman yang banyak mengandung metabolit sekunder adalah tanaman maja (Aegle marmelos (L.) Corr). Tanaman maja atau disebut juga dengan mojo, adalah sejenis tumbuhan subtropis yang mudah tumbuh dan berkembang di hampir seluruh wilayah di Indonesia. Buah maja sering digunakan sebagai obat tradisional. Buah yang matang dapat di iris, dikeringkan dan digunakan sebagai obat disentri kronis, diare, dan sembelit. Kulit batangya digunakan untuk meracuni ikan. Akar maja digunakan sebagai obat penenang debaran jantung, gangguan pencernaan, dan tukak lambung. Daun maja mengandung saponin dan tannin, disamping itu akar dan kulit batangnya mengandung flavonoid, saponin, dan polifenol. Selain itu getah maja juga dapat digunakan sebagai obat pharmaceutical yang berfungsi sebagai perekat untuk obat-obatan tablet (Patil et al, 2010).

Pada penelitian sebelumnya Amit dan Rashmi (2011) menyatakan bahwa kandungan buah maja diantaranya alkaloid, terpenoid, polifenol, saponin, tanin, dan plobatanin. Pada penelitian lain juga disebutkan pula kandungan buah maja diantaranya alkaloid, flavonoid, fenol dan tanin (Sridhar 2014). Buah maja mengandung komponen tanin 9\%, sedangkan pada kulit buah maja mencapai 20\% (Naresh et al., 2012)

Melihat manfaat dan kandungan senyawa metabolit sekunder yang dimiliki buah maja (Aegle marmelos (L.) Corr) yang belum banyak diketahui oleh masyarakat, maka diperkirakan buah tersebut memiliki potensi dalam pengobatan penyakit. Aktivitas biologi buah maja juga belum banyak diketahui oleh masyarakat secara luas. Salah satu aktivitas biologi yang diduga terdapat pada buah maja adalah antioksidan. Antioksidan memiliki peranan yang penting bagi tubuh manusia dalam menangkal serangan radikal bebas atau kerusakan yang terjadi akibat radikal bebas.

Berdasarkan hal tersebut, perlu dilakukan penelitian lebih dalam mengenai uji kualitatif meliputi uji flavonoid, alkaloid, tanin, saponin, dan glikosida, serta uji aktivitas antioksidan dengan metode DPPH

\section{B. Landasan Teori}

Alat

Alat yang digunakan dalam penelitian antara lain: timbangan elektrik, gelas beker, gelas ukur, batang pengaduk, sendok tanduk, corong, kertas saring, kain flanel, cawan porselin, bunsen, kaki tiga, pipet tetes, pipet ukur, mikropipet, stirer, tabung reaksi, rak tabung reaksi, objeck glass, stop watch, spektrofotometer UV-Vis (Genesys 10s), lempeng KLT, bejana kromatografi dan tutup bejana, pipa kapiler, dan kertas penjenuh.

\section{Bahan}

Bahan yang digunakan dalam penelitian antara lain:buah maja, vitamin C, DPPH (sigma aldrich), etanol 70\%, silika gel $60 \mathrm{~F} 254$, metanol, butanol, etil asetat, air, asam asetat, aquadest, etanol absolute (Merck, 99.8\%), $\mathrm{HCl} 2 \mathrm{~N}, \mathrm{H} 2 \mathrm{SO} 4$, reagen bauchardat atau mayer, gelatin, sudan III (Merck, 25gr).

\section{Pengambilan dan Pengolahan Sampel}

Sampel buah maja (Aegle marmelos (L.) Correa) diperoleh dari daerah Slerok, Tegal, Provinsi Jawa Tengah. Buah maja dipisahkan dengan kulitnya kemudian daging buah maja diambil di iris tipis-tipis, kemudian diangin-anginkan di tempatyang teduh atau tidak terkena sinar matahari langsung dan ditutup dengan kain hitamsampai kering. Tujuannya adalah simplisia tidak mudah rusak dan tidak terjadi kerusakan komposisi kandungan senyawa dalam buah maja. Simplisia yang sudah kering diblender dan diayak dengan ayakan ukuran 40 mesh. 


\section{Ekstraksi Sampel}

Simplisia kering buah maja (Aegle marmelos (L.)Correa) sebanyak 100 gram dimasukkan ke dalam wadah maserasi, lalu ditambahkan pelarut etanol $70 \%$ sebanyak $750 \mathrm{ml}$ hingga simplisia tersebut terendam, dibiarkan selama 5 hari dalam bejana tertutup dan terlindungi dari cahaya matahari langsung sambil diaduk secara periodik, setelah 5 × 24 jam dilakukan penyaringan untuk diperoleh ekstrak etanol 70\% cair. Setelah itu, ampasnya dimaserasi kembali dengan cairan penyari yang baru. Hasil penyarian yang diperoleh kemudian diuapkan dengan menggunakan waterbath $70^{\circ} \mathrm{C}$ (Dirjen POM, 2000).

\section{Uji Kualitatif}

Uji kualitatif yang dilakukan pada ekstrak buah maja (Aegle marmelos (L.)Correa) meliputi uji flavonoid, uji alkaloid, uji tanin, uji saponin, dan uji glikosida.

1. Uji Flavonoid

Pengujian dilakukan dengan cara mengambil masing-masing sebanyak $2 \mathrm{~mL}$ sampel buahmaja yang telah diekstraksi dengan pelarut air dan etanol, kemudian dipanaskan kurang lebih 5 menit. Setelah dipananskan masing-masing dutambahkan dengan 0,1 gram logam $\mathrm{Mg}$ dan 5 tetes $\mathrm{HCl}$ pekat. Jika masing-masing larutan terbentuk warna kuning jingga sampai merah, maka positif mengandung flavonoid (Mustikasari \& Ariyani, 2010)

2. Uji Alkaloid

Pengujian dilakukan dengan mengambil masing-masing $2 \mathrm{~mL}$ sampel buah maja yang telah diekstraksi dengan pelarut air dan etanol ke dalam 2 buah tabung reaksi yang berbeda. Setelah itu masing-masing ekstrak ditambah dengan 5 tetes reagen Dragendroff. Jika masing-masing larutan terbentuk endapan jingga maka positif mengandung alkaloid. Selanjutnya utuk pengujian Alkaoid dengan menggunakan reagen mayer dilakukan dengan cara mengambil masing-masing sebanyak $2 \mathrm{~mL}$ sampel buah maja yang telah diekstraksi dengan pelarut air dan etanol ke dalam 2 buah tabung reaksi yang berbeda. Setelah itu masing-masing ekstrak ditambah 3 tetes asam klorida pekat dan 5 tetes reagen Mayer. Jika masing-masing larutan terbentuk endapan putih maka sampel positif mengandung alkaloid (Mustikasari \& Ariyani, 2010)

3. Uji Tanin

Pengujian dilakukan dengan cara mengambil masing-masing sebanyak $2 \mathrm{~mL}$ sampel buah maja yang telah diekstraksi dengan pelarut air dan etanol, kemudian dipanaskan kurang lebih 5 menit. Setelah dipanaskan masing-masing ditambahkan beberapa tetes $\mathrm{FeCl} 3$ $1 \%$. Jika masing-masing larutan terbentuk warna coklat kehijauan atau biru kehitaman maka positif mengandung tanin (Marlinda dkk, 2012).

Pengujian tanin yang kedua $1 \mathrm{ml}$ filtrat dipindahkan kedalam tabung reaksi dan ditambahkan 2-3 tetes gelatin $1 \%$. Hasil positif menunjukkan terbentuknya endapan putih (Kumoro, 2015)

4. Uji Saponin

Pengujian dilakukan dengan cara mengambil $1 \mathrm{~g}$ serbuk simplisia dipanaskan dengan 100 $\mathrm{mL}$ akuades hingga mendidih selama 5 menit kemudian disaring dan diperoleh ekstrak air. $10 \mathrm{~mL}$ ekstrak air digojok secara vertikalselama 10 menit, kemudian ditambahkan beberapa tetes $\mathrm{HCl} 2 \mathrm{~N}$ jika terbentuk busa dengan mantap mengindikasi mengandung saponin (Handayani dkk., 2017).

5. Uji Glikosida

Pengujian dilakukan dengan cara mengambil masing-masing sebanyak $2 \mathrm{~mL}$ sampel buah maja yang telah diekstraksi dengan pelarut air dan etanol, kemudian dipanaskan kurang lebih 5 menit. Kemudian tambahkan $5 \mathrm{ml}$ asam asetat anhidrat dan 10 tetes $\mathrm{H}_{2} \mathrm{SO}_{4}$ pekat. Amati perubahan warna yang terjadi jika terbentuk warna biru/hijau menandakan adanya senyawa glikosida (Depkes RI, 1989).

\section{Uji Kromatografi Lapis Tipis}

Bejena pengembang (chamber) dijenuhi dengan fase gerak yang sesuai untuk golongan senyawa aktif. fase gerak flavonoid adalah butanol : asam asetat : air $(1: 4: 5)$. Totolkan 
ekstrak pada lempeng KLT (silika gel 60 F254) untuk flavonoid, pastikan ekstrak yang ditotolkan sampai kering. Kemudian lempeng KLT dielusi, dikeringkan kemudian dideteksi sinar UV $\lambda 254 \mathrm{~nm}$ dan $365 \mathrm{~nm}$. Kemudian dihitung Rf dan HRfnya.

\section{Pembuatan blanko DPPH 0,1 mM}

Serbuk DPPH ditimbang sebanyak 3,9 mg dan dilarutkan dalam etanol p.a sampai tepat 100,0 $\mathrm{mL}(0,1 \mathrm{mM})$ (Khasanah et al., 2014).

\section{Pembuat pembanding vitamin $\mathrm{C}$}

Vitamin C sebanyak 0,5 mg ditambahkan air sampai 50,0 ml sehingga diperoleh kadar $1 \%$. Dari kadar ini dibuat seri konsentrasi sebesar 10, 15, 20, 25 dan $30 \mu \mathrm{g} / \mathrm{mL}$.

\section{Pembuatan kadar sampel vitamin C}

Ekstrak etanol buah maja ditimbang dengan seksama 0,1 gram, kemudian dilarutkan dengan metanol sampai $50 \mathrm{ml}$, sehingga diperoleh kadar 1\%. Dari kadar 1\% dibuat seri konsentrasi sebesar 100, 150, 200, 250 dan 300 ppm. (Williams, 1995)

\section{Penentuan panjang gelombang maksimal larutan DPPH 0,1 mM}

Penentuan panjang gelombang $(\lambda)$ dengan cara mengukur 4,0 mL larutan DPPH 0,1 mM pada spektrofotometer dengan panjang gelombang 400-600 nm untuk mendapatkan absorbansi \pm 0,2-0,8 (Khasanah et al., 2014).

\section{Penentuan operating time larutan DPPH 0,1mM}

Penentuan operating time dilakukan dengan cara mereaksikan $50 \mu 1$ baku pembanding vitamin C ditambah 4,0 mL larutan DPPH 0,1 mM, dihomogenkan dengan stirer selama 1 menit dan diukur absorbansinya pada menit ke $0,5,10,15,20,25,30,35,40,45,50,55$, dan 60 pada $\lambda$ maksimal yang sudah diperoleh (Khasanah et al., 2014).

\section{Uji aktivitas antioksidan dengan metodeDPPH}

Sebanyak 4,0 mL DPPH 0,1 mM dimasukkan tabung reaksi, tambahkan 50,0 $\mu \mathrm{L}$ ekstrak etanolik buah maja dengan berbagai konsentrasi, kemudian distirer 1 menit sampai homogen dan diamkan selama 30 menit ditempat gelap, baca absorbansinya pada $\lambda$ maksimal $(515 \mathrm{~nm})$. Untuk uji aktivitas baku pembanding vitamin C perlakuannya sama.

\section{Analisa Data}

Data nilai absorbansi dari ekstrak etanolik Aegle marmelos serta baku pembanding, dihitung dengan rumus: $\%$ aktivitas antioksidan $=$ Absorbansi blanko $($ Absorbansi DPPH) - Absorbansi sampel (Absorbansi ekstrak etanolik Aegle marmelos dan vitamin C dibagi Absorbansi blanko (Absorbansi DPPH) dikali 100\%. Data diolah menggunakan analisa probit antara log konsentrasi larutan uji (x) dengan persentase aktivitas antioksidan (y) sehingga diperoleh IC50. Untuk mengetahui perbedaan aktivitas antioksidan antara ekstrak etanolik Aegle marmelos digunakan uji.

\section{Hasil Penelitian dan Pembahasan}

Penelitian ini menggunakan buah maja (Aegle marmelos (L.) Correa) untuk memberikan data secara ilmiah. Metode ekstraksi yang digunakan adalah metode maserasi yang merupakan metode ekstraksi dingin, dimana metode ini tidak merusak komponen kimia pada buah maja, karena tidak adanya pemanasan yang terjadi dalam proses ekstraksi, namun membutuhkan waktu yang lama dibandingkan proses ekstrasi yang lainnya.

Ekstraksi yang dilakukan menggunakan pelarut etanol $70 \%$ yang merupakan pelarut polar yang bersifat tidak toksik. Selain itu, pelarut etanol $70 \%$ memiliki keistimewaan tersendiri yaitu dapat menyari komponen kimia yang bersifat polar maupun yang bersifat non polar. Hasil maserasi kemudian dipekatkan dengan menggunakan waterbath sehingga diperoleh ekstrak kental yang kemudian dihitung rendamen ekstrak. Rendamen ekstrak dihitung dengan cara membandingkan jumlah ekstrak yang diperoleh dengan simplisia awal yang digunakan. Adapun Besar rendamen hasil ekstraksi $100 \mathrm{~g}$ buah maja dalam $750 \mathrm{~mL}$ etanol $70 \%$ yang dihitung berdasarkan persen rendamen ekstrak yaitu 36,69\%. 
Hasil ekstrak etanolik dari buah maja (Aegle marmelos (L.) Correa) kemudian dilakukan uji kualitatif metabolit sekunder menggunakan pereaksi warna yang meliputi uji alkaloid, flavonoid, glikosida, saponin, dan tanin. Uji kualitatif bertujuan untuk identifikasi awal dalam mengetahui golongan senyawa bioaktif yang terhadap dalam simplisia dan ekstrak sebagai langkah penting dalam penentuan potensi aktivitasnya sebagai obat (Simaremare, 2014). Senyawa bioaktif sering juga disebut dengan senyawa metabolit sekunder. Berdasarkan hasil penelitian yang dilakukan, ekstrak buah maja mengandung senyawa metabolit sekunder alkaloid, flavonoid, glikosida, saponin, dan tanin.

Tabel 1. Hasil Uji Kualitatif Buah Maja (Aegle marmelos (L.)Correa)

\begin{tabular}{lc}
\hline Skrining Fitokimia & Hasil \\
\hline Alkaloid & + \\
Flavonoid & + \\
Glikosida & + \\
Saponin & + \\
Tanin & +
\end{tabular}

Keterangan :

(+) Mengandung senyawa metabolit sekunder yang diujikan

(-) Tidak mengandung senyawa metabolit sekunder yang diujikan

Pengujian aktivitas anti radikalbebas secara kualitatif dilakukan dengan menggunakan KLT. Sampel ditotolkan pada lempeng KLT kemudian dielusi menggunakan cairan pengelusi (eluen) $n$ - butanol : asam asetat : air (4:1:5), karena cairan pengelusi ini biasa digunakan untuk flavonoid (Harborne, 1989). Hasil pengujian memperlihatkan bercak kuning menyala dalam sinar UV $366 \mathrm{~nm}$ pada nilai Rf 0,512 pada ekstrak etanol 70\%. Bercak yang memberikan perubahan warna ungu menjadi kuning menunjukkan adanya aktivitas anti radikal bebas. Hasil KLT dapat dilihat pada table 2 .

Tabel 2. Hasil KLT Buah Maja (Aegle marmelos (L.) Correa)

\begin{tabular}{|c|c|c|c|}
\hline Sampel & $\mathrm{Rf}$ & $\begin{array}{c}\text { UV } \\
254 \\
\text { Warna }\end{array}$ & $\begin{array}{c}\text { UV } 366 \\
\text { Warna }\end{array}$ \\
\hline $\begin{array}{c}\text { Ekstrak } \\
\text { Etanolik } \\
\text { Buah } \\
\text { Maja }\end{array}$ & 0,512 & $\begin{array}{c}\text { Kunin } \\
\mathrm{g}\end{array}$ & $\begin{array}{l}\text { Kuning } \\
\text { menyala }\end{array}$ \\
\hline
\end{tabular}

1. Fase gerak: n-Butanol : Asam Asetat : Air

2. Fase diam : silika gel $60 \mathrm{~F} 254$

3. Ukuran: $10 \times 3 \mathrm{~cm}$

Penentuan panjang gelombang maksimal larutan DPPH 0,1 mM terhadap absorbansi diperoleh hasil absorbansi sebesar 1,23A pada panjang gelombang $515 \mathrm{~nm}$, sehingga pengujian sampel dan kontrol positif dilakukan pada panjang gelombang $515 \mathrm{~nm}$. 
Hasil penentuan operating time vitamin C dengan DPPH 0,1 mM diperoleh pada menit ke 40. Maka pengujian aktivitas antioksidan dilakukan pada menit ke 40.

Pengujian aktivitas antioksidan dilakukan secara kuantitatif dengan menggunakan metode yang dilakukan Khasanah et al., (2014). Diperoleh hasil pada gambar 1.

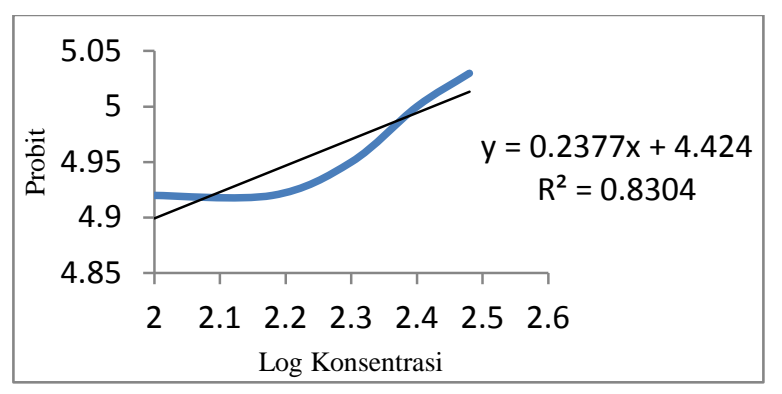

Gambar 1. Grafik aktivitas antioksidan ekstrak etanolik buah maja

Dapat diketahui bahwa semakin tinggi konsentrasi sampel yang digunaka maka aktivitas antioksidan juga semakin besar, ditandai dengan berkurangnya intensitas warna menggambarkan penurunan konsentrasi DPPH yang diberi sampel maupun pembanding. Semakin besar aktivitas peredaman radikal DPPH maka konsentrasi DPPH yang masih ada semakin kecil, sehingga nilai absorbansi yang dihasilkan semakin turun

Perolehan Inhibition Concentration ${ }_{50}\left(\mathrm{IC}_{50}\right)$ dan Analisis Data pada ekstrak buah maja dan vitamin $\mathrm{C}$ sebagai pembanding diperoleh hasil pada tabel 3 dan 4 .

Tabel 3. Hasil Aktivitas Antioksidan Vit. C

\begin{tabular}{cccc}
\hline & $\begin{array}{c}\text { Konsen } \\
\text { trasi }\end{array}$ & & \\
Sampel & Nampel & Probit & $(\mu \mathrm{g} / \mathrm{ml})$ \\
& $(\mu \mathrm{g} / \mathrm{ml})$ & & \\
& 10 & 5,50 & $\mathrm{Y}=1,333 \mathrm{x}-3,053$ \\
& 20 & 5,50 & $\mathrm{R}^{2}=0,333$ \\
Vitamin & & & \\
C & 40 & 5,52 & $\mathrm{IC} 50=28,907$ \\
& 80 & 5,52 & \\
\hline
\end{tabular}

Tabel 4. Hasil Aktivitas Antioksidan Buah Maja (Aegle marmelos (L.)Correa)

\begin{tabular}{cccc}
\hline & $\begin{array}{c}\text { Konsen } \\
\text { trasi }\end{array}$ & & \\
Sampel & sampel & Probit & Nilai IC $_{50}$ \\
& & & $(\mu \mathrm{g} / \mathrm{ml})$ \\
& $(\mu \mathrm{g} / \mathrm{ml})$ & & \\
\hline $\begin{array}{c}\text { Ekstrak } \\
\text { Buah }\end{array}$ & 100 & 4,92 & $\mathrm{Y}=0,237 \mathrm{x}-4,424$ \\
& 150 & 4,92 & $\mathrm{R}^{2}=0,830$
\end{tabular}




\begin{tabular}{|c|c|c|c|}
\hline \multirow[t]{3}{*}{ Maja } & 200 & 4,95 & IC50 = 269,153 \\
\hline & 250 & 5 & \\
\hline & 300 & 5,03 & \\
\hline
\end{tabular}

Dari tabel diketahui bahwa $\mathrm{IC}_{50}$ vitamin $\mathrm{C}$ adalah 28,907 dan sampel ekstrak buah maja adalah $269,153 \mu \mathrm{g} / \mathrm{ml}$. Hal ini menunjukkan bahwa daya aktivitas antioksidan ekstrak etanolik buah maja lebih kecil disbanding dengan daya aktivitas antioksidan vitamin $\mathrm{C}$ dengan menggunakan metode DPPH. Hal ini dikarenakan kadar vitamin $\mathrm{C}$ dan flavonoid yang terkandung dalam ekstrak etanolik buah maja lebih sedikit disbanding dengan vitamin $\mathrm{C}$ murni yang merupakan senyawa tunggal yang potensial sebagai antioksidan.

Menurut Phongpaichit et al (2007), Suatu senyawa dikatakan sebagai antiradical bebas sangat kuat apabila nilai $\mathrm{IC}_{50}<10 \mu \mathrm{g} / \mathrm{mL}$, kuat apabila nilai $\mathrm{IC}_{50}$ antara $10-50 \mu \mathrm{g} / \mathrm{mL}$, sedang apabila nilai $\mathrm{IC}_{50}$ berkisar antara 50-100 $\mu \mathrm{g} / \mathrm{mL}$, lemah apabila nilai $\mathrm{IC}_{50}$ berkisar antara 100-250 $\mu \mathrm{g} / \mathrm{mL}$ dan tidak aktif apabila $\mathrm{IC}_{50}$ diatas $250 \mu \mathrm{g} / \mathrm{mL}$. Hal ini menunjukan aktivitas antioksidan buah maja tidak aktif.

\section{Kesimpulan}

Hasil uji kualitatif menunjukan bahwa buah maja mengandung metabolit sekunder alkaloid, flavonoid, glikosida, saponin, dan tanin. Sedangkan hasil ekstrak etanolik buah mempunyai aktivitas antioksidan dengan nilai IC $_{50}$ ekstrak etanolik buah maja sebesar $269,153 \mu \mathrm{g} / \mathrm{ml}$ dan pada vitamin C sebasar $28,907 \mu \mathrm{g} / \mathrm{ml}$.

\section{Daftar Pustaka}

[1] Direktorat Jenderal Pengawasan Obat dan Makanan. (2013). Peraturan Kepala Badan Pengawasan Obat dan Makanan Republik Indonesia tentang Penerapan Pedoman Cara Pembuatan Obat yang Baik. Peraturan Kepala Badan Pengawasan Obat Dan Makanan Republik Indonesia Tentang Penerapan Pedoman Cara Pembuatan Obat Yang Baik.

[2] Handayani, S., Wirasutisna, K. R., \& Insanu, M. (2017). Penapisan Fitokimia dan Karakterisasi Simplisia Daun Jambu Mawar (Syzygium jambos Alston). Jf Fik Uinam.

[3] Harborne, J. B. (1987). Metode Fitokimia, Penuntun Cara Modern Menganalisis Tumbuhan. ITB.

[4] Kumoro, A. C., Hasan, M., \& Singh, H. (2009). Effects of solvent properties on the Soxhlet extraction of diterpenoid lactones from Andrographis paniculata leaves. ScienceAsia. https://doi.org/10.2306/scienceasia1513-1874.2009.35.306

[5] Marlinda, M., Sangi, M. S., \& Wuntu, A. D. (2012). Analisis Senyawa Metabolit Sekunder dan Uji Toksisitas Ekstrak Etanol Biji Buah Alpukat (Persea americana Mill.). Jurnal MIPA. https://doi.org/10.35799/jm.1.1.2012.427

[6] Mustikasari, K., \& Aryani, D. (2010). Skrining fitokimia ekstrak metanol biji kalangkala (Litsea angulata). Jurnal Sains Dan Terapan Kimia.

[7] Naresh, C., Adarsh, M., Mehta, \& Dodia. (2012). Primary identification of certain phytochemical constituents of aegle marmelos (1.) Corr. Serr responsible for antimicrobial activity against selected vegetable and clinical pathogen. International Journal of Physical and Social Sciences.

[8] Nugraheni. (2007). Perbandingan Aktivitas Antioksidan Ekstrak Metanol dan Ekstrak Etanol Daun Tempuyung (Sunchus arvensis L.) serta Penentuan EC50 dengan Metode DPPH (1,1- difenil-2-pikrilhidrazil).

[9] Pandey, A., \& Mishra, R. (2011). Antibacterial properties of Aegle marmelos leaves, fruits and peels against various pathogens. Journal of Pharmaceutical and Biomedical 
Sciences.

[10]Patil, D. N., Kulkarni, A. R., \& Patil, B. S. (2010). Fruit gum of Aegle marmelos as pharmaceutical aid. International Journal of Pharmacology. https://doi.org/10.3923/ijp.2010.68.71

[11]Phongpaichit, S., Nikom, J., Rungjindamai, N., Sakayaroj, J., Hutadilok-Towatana, N., Rukachaisirikul, V., \& Kirtikara, K. (2007). Biological activities of extracts from endophytic fungi isolated from Garcinia plants. FEMS Immunology and Medical Microbiology. https://doi.org/10.1111/j.1574-695X.2007.00331.x

[12]Simaremare, E. S. (2014). Skrining Fitokimia Ekstrak Etanol Daun Gatal (Laportea decumana (Roxb.) Wedd). Pharmacy.

[13]Sridhar, N., Raghavendra, M., Prasad, M.N.V., Kiran, B.V.V.S.S., Kanthal, L.K. (2014). Screening the fruits of Aegle marmelos for antibacterial, Anthelmintic and Cardiotonic Properties. International Journal of Pharma Research \& Review, 3, 48-55.

[14]Williams, W. B., Cuvelier, M. E. C., \& Berset, C. (1995). Use of a Free Radical Method to Evaluate Antioxidant Activity. Iwt, 28(1), 25-30.

[15]Yuhernita, J. (2011). Analisis Senyawa Metabolit Sekunder Dari Ekstrak Metanol Daun Surian Yang Berpotensi Sebagai Antioksidan. MAKARA of Science Series, 15(1), 4852. 